DIGITAL COMMONS
@ UNIVERSITY OF SOUTH FLORIDA

Volume 10

Issue 1 Spring 2020

\section{ABO: Interactive Journal for Women in the Arts, 1640-1830}

Article 5

2020

\title{
A Review of Joanna Wharton, Material Enlightenment: Women Writers and the Science of the Mind, 1770-1830
}

Kandice Sharren

Simon Fraser University, ksharren@sfu.ca

Follow this and additional works at: https://digitalcommons.usf.edu/abo

Part of the Dramatic Literature, Criticism and Theory Commons, Educational Methods Commons, Feminist, Gender, and Sexuality Studies Commons, and the Literature in English, British Isles Commons

\section{Recommended Citation}

Sharren, Kandice (2020) "A Review of Joanna Wharton, Material Enlightenment: Women Writers and the Science of the Mind, 1770-1830," ABO: Interactive Journal for Women in the Arts, 1640-1830: Vol.10: Iss.1, Article 5. http://doi.org/10.5038/2157-7129.10.1.1232

Available at: https://digitalcommons.usf.edu/abo/vol10/iss1/5

This Reviews is brought to you for free and open access by Digital Commons @ University of South Florida. It has been accepted for inclusion in ABO: Interactive Journal for Women in the Arts, 1640-1830 by an authorized administrator of Digital Commons @ University of South Florida. For more information, please contact digitalcommons@usf.edu. 


\title{
A Review of Joanna Wharton, Material Enlightenment: Women Writers and the
} Science of the Mind, 1770-1830

\author{
Abstract \\ A Review of Joanna Wharton, Material Enlightenment: Women Writers and the Science of the Mind, \\ $1770-1830$, by Kandice Sharren \\ Creative Commons License \\ (c) (i) (9)
}

This work is licensed under a Creative Commons Attribution-Noncommercial 4.0 License 
Joanna Wharton, Material Enlightenment: Women Writers and the Science of the Mind, 1770-1830 Boydell \& Brewer, 2018. 288 pp. ISBN: 978178327952

Reviewed by Kandice Sharren

Simon Fraser University

In Essay Concerning Human Understanding (1689), John Locke first laid out the argument that people are not born with innate ideas and instead develop them through sensation and reflection. Locke's theory marked a profound departure from previous philosophies of the mind and had a profound effect on how human consciousness was understood. While traditionally the mind or soul had been understood as immaterial, by the end of the eighteenth century, consciousness increasingly came to be conceived of as fundamentally embodied and shaped by the material world. In Material Enlightenment: Women Writers and the Science of Mind, 1770-1830 Joanna Wharton explores how this philosophical shift allowed women writers to claim new forms of cultural authority and to play a pivotal role in "the pre-disciplinary development of psychological theory and practice in late eighteenth-century Britain" (6). In a wide-ranging discussion of conservative, liberal, and dissenting thinkers, Wharton offers an important revision to scholarship that has emphasized the relationship between materialist philosophies and radical thought in the Romantic period.

Identifying Locke as a turning point in proto-psychology, Wharton opens with a rigorous and accessible framework that traces the eighteenth-century shift towards an understanding of the mind as material, especially how this mode of thought influenced early feminist and educational philosophies. She traces Locke's ideas through David Hartley's associationist theory and Thomas Paine's popularization of it, to show how materialist philosophy came to be associated with radical thought, then makes a compelling case for reconsidering its influence on a wider range of intellectual traditions. Through sustained analysis of Anna Letitia Barbauld, Honora Edgeworth, Hannah More, Elizabeth Hamilton, and Maria Edgeworth, Material Enlightenment links debates about the role of women to eighteenth-century material psychology by way of their educational and literary writing. Ultimately, Wharton argues that "a small group of women developed philosophical languages of materiality that revolutionised educational and philosophical practice, and ... in doing so helped initiate profound (though by no means unambiguous) psychological, social and political change" (23).

The first two chapters focus on the role of Lockean associationism in educational writing. Chapter One, "Things themselves," draws on Barbauld's Lessons for Children and Hymns in Prose to explore how, in these works, "objects take centre 
stage as the means by which ideas, social affections and devotional taste are communicated to the mind and implanted in the heart" (34). In a virtuosic argument that links the materialist philosophy that informs Barbauld's educational writing to the material book that child readers and their parents engage with, Wharton shows how Barbauld fosters habitual religious devotion in young readers by inviting them into joyful encounters with the natural world, a process that links "physical, practical doing ... [with] abstract thinking" (37). However, Barbauld's educational strategy has implications beyond her attempts to inculcate religious devotion in her child readers. As Wharton points out, the strategies that Barbauld adopts in her children's writing "suggests a rejection of gender distinctions in the proper content and form of literature for boys and girls" (66).

The second chapter, "Honora Edgeworth and the 'experimental science' of education," further develops the importance of material psychology to late eighteenth-century theories of education. Drawing on the manuscript notes that would later form the basis for Practical Education (1798), a book jointly attributed to Honora's step-daughter Maria and husband Richard Lovell, Wharton argues that "Honora's work formed the basis for an educational system of 'practice' and 'experience' . . . and set a precedent for familial collaboration in the decades to come" (78). With its focus on the importance of cultivating attention as an essential building block for rational education in both Honora's notebooks and Practical Education, this chapter again considers how representations of the material world in writing for and about children can be used to shape their habits and abilities, in this case with the aim of producing obedient, rational children rather than devout ones. The section that addresses the struggle between Anna Seward and the Edgeworth family over the posthumous image of Honora as, respectively, either a sentimental friend or "exemplary wife and mother, and, moreover, as a pioneer of scientific educationalism" (89) is particularly illuminating for its illustration of the stakes of early educational psychology for the women who engaged with it. Linking that struggle more explicitly with the chapter's discussion of Edgeworthian educational practices would better support its conclusion that Honora's writing "reveal[s] continuities and breaks between emotion and Enlightenment empiricism at the interface between domestic and scientific worlds" (111).

The third and fourth chapters highlight the political stakes of women's engagement with the science of the mind. Chapter Three, "Profession and occlusion" argues that Hannah More sought to appropriate materialist philosophy from republican thinkers, employing it in service of conservative Christian practices. The first half of the chapter considers education outside of a domestic context, by turning to Mendip schools that More and her sister founded, as well as the Cheap Repository Tracts that More authored in an attempt to inculcate Christian principles in the 
lower classes. By highlighting the evangelical and conservative uses of Lockean associationism, this first half of the chapter demonstrates the sinister potential of materialist psychology, especially how it could be used to reinforce class distinctions. The second half turns to More's Strictures on the Modern System of Female Education (1799) and her highly successful novel Coelebs in Search of a Wife (1808), showing how More drew on associationist philosophy in her writing for middle- and upper-class women to represent charity as a Christian practice rooted in personalized acts of benevolence and self-regulation. Together, the two halves of this chapter present a bifurcated argument about how associationism could assuage class anxieties by conditioning middle- and upper-class women and their working-class counterparts into prescribed relations.

In turning to Elizabeth Hamilton in the fourth chapter, "Clearing out the "rubbish,", Wharton more fully addresses how Lockean associationism provides the grounds for women to claim cultural authority. This chapter shows how Hamilton uses the language of associationist philosophy to simultaneously justify her self-education and critique the exclusivity of the philosophical tradition after Locke in Letters on the Elementary Principles of Education (1801), Translation of the Letters of a Hindoo Rajah (1796), and Memoirs of Modern Philosophers (1800). In the book's clearest articulation of the stakes of material philosophy for women, Wharton argues that Hamilton's critique is gendered; by positioning "women as practical, and thus superior treasurers of philosophical learning" (165), she lays claim to materialist philosophy as the proper domain of women, whose empirical experience outweighs their institutionalized learning.

The fifth and final chapter links the educational and political threads of Wharton's argument more explicitly in its discussion of Maria Edgeworth, whose educational writing overlapped with the political and social questions involved in the running of her father's estate. Situating Edgeworth's educational writing in the context of the political unrest in Ireland at the turn of the nineteenth century, this chapter synthesizes the two threads of criticism about Edgeworth's writing that are often distinct. Picking up where the second chapter left off, this chapter asks how Edgeworth's use of associationist theory in "her annotative writings might thus be seen as material interventions into the knowledge economy that bind Britain and Ireland together with the currency of 'fact,' while preserving or newly inscribing cultural differences" (204). Tied to these issues, and to the question of empire more generally, is the role of technology, which Edgeworth addresses through representations of mechanical toys which balance the goal of "industrious improvement" (228) against "the vital necessity of the literary imagination to material enlightenment" (230). 
The complexity of Wharton's argument inevitably leads to some threads being emphasized at the expense of others. Wharton's focus on a mix of conservative, liberal, and dissenting women offers a complex picture of how women of various political leanings engaged with the science of the mind, but at various points throughout the book, radical thinkers-especially William Godwin, Mary Wollstonecraft, and Mary Hays - become essential interlocutors, especially in the third and fourth chapters. Perhaps not coincidentally, these are the moments in which the stakes of the argument are the clearest. However, threading the discussion of radical thought throughout the introduction and these chapters dilutes it, limiting the force of Wharton's argument overall. A more comprehensive and concentrated analysis of how radical writers engaged with materialist thought would allow the political implications of More's and Hamilton's writing to emerge more fully. The fifth chapter does some of the work of linking the emphasis on education in the first and second chapters to the political focus of the third and fourth, but the political implications of the first two chapters could be highlighted more clearly. Nevertheless, Material Enlightenment is an energetic and exciting contribution to scholarship about a philosophical tradition that has primarily been considered in the context of radical writing. Its wide-ranging engagement with late eighteenth-century educational and political debates means that it will be of interest to anyone invested in scientific, philosophical, or proto-feminist debates during the period in question. 